\title{
CHEMICAL STUDY OF LEAVES OF Chrysophyllum marginatum (HOOK. \& ARN.) RADLK (SAPOTACEAE)
}

Viviane Cândida da Silva, Márcia Nasser Lopes* e Vanderlan da Silva Bolzani

Departamento de Química Orgânica, Instituto de Química, Universidade Estadual Paulista "Júlio de Mesquita Filho", CP 355, 14801-970 Araraquara - SP, Brasil

Recebido em 5/4/05; aceito em 12/8/05; publicado na web em 8/2/06

\begin{abstract}
The fractionation of the antioxidant ethyl acetate extract obtained from the dried leaves of Chrysophyllum marginatum afforded six substances identified as: $\alpha$-amirin, gallic acid, myricitrin, quercitrin, (-)-epigallocatechin and (-)-epigallocatechin-3-O-gallate. This study contributes to the knowledge of the secondary metabolites produced by one more species of the Brazilian Flora, until now not investigated. Moreover, this study allowed the identification of three substances with antioxidant activity previously detected in this species.
\end{abstract}

Keywords: Sapotaceae; Chrysophyllum marginatum; antioxidant.

\section{INTRODUCTION}

Chemical and biological studies of Sapotaceae species from Brazil are scarce. The family comprises 1100 species included in 53 genera $^{1}$. Sapotaceae species provide economically important products such as latex for gutta percha and chewing gum, hard and durable wood, and many edible fruits ${ }^{2}$. Chemically, the family is characterized by the presence of triterpenoids and steroids, which are used as chemotaxonomic markers ${ }^{3}$ in Argania $^{4}, M_{\text {adhuca }}^{5}$, Mimusops $^{6}$, and Sideroxylon ${ }^{7}$.

Chrysophyllum marginatum, commonly known as aguai-vermelho or guatambu-de-leite, is distributed in states of Bahia, Goias until Rio Grande do Sul. The plant can reach 10 meters of height, and possesses simple and alternating leaves, small and perfumed flowers, fruits with succulent pulp, black when ripe, which are consumed by the birds in general. Wood is used at carpentry and as coal ${ }^{8}$.

The lack of chemical information about Chrysophyllum together with the presence of antioxidant polyphenolics in the fruits of Chrysophyllum cainito ${ }^{9}$ prompted us to take up phytochemical investigation on the $C$. marginatum.

\section{RESULTS AND DISCUSSION}

The ethanol extract of the dried and powdered leaves of $C$. marginatum was partitioned into hexane, ethyl acetate and $n$ butanol. The ethyl acetate layer showed antioxidant activity using $\beta$-carotene/TLC assay. This extract was fractioned on Sephadex LH-20, eluted with MeOH. After analysis by TLC, collected fractions were combined, resulting in 30 subfractions. Without subsequent stages of purification, three subfractions were identified as gallic acid $\underline{\mathbf{2}}$, myricitrin $\underline{\mathbf{4}}$ and (-)-epigallocatechin3-O-gallate ‥ Subfraction 4 was submitted to column chromatography on silica flash, and after TLC, some fractions were combined and one of them was identified as $\alpha$-amirin $\underline{\mathbf{1}}$. Subfraction 11 and 14 were submitted to preparative TLC, yielding compounds quercitrin $\underline{\mathbf{3}}$ and (-)-epigallocatechin $\underline{\mathbf{5}}$, respectively. All compounds isolated (Figure 1) are known and were identified by spectroscopic means and by comparison with literature data ${ }^{10-13}$, mainly ${ }^{13} \mathrm{C}$ NMR $\delta$ values.

*e-mail: mnlopes@iq.unesp.br
The ${ }^{13} \mathrm{C}$ NMR of $\underline{\mathbf{1}}$ showed signals at $\delta 126.1,139.7,39.8$ (2x) and 17.6 corresponding, respectively, to C-12, C-13, C-19, C-20 and C-29, that corroborate the ursane structure to the compound. The ${ }^{1} \mathrm{H}$ NMR of $\underline{\mathbf{3}}$ and $\underline{\mathbf{4}}$ showed signals that suggested the structure of quercetin and miricetin, respectively, for the aglycones of the compounds. In both spectra signals corresponding to a rhamnose sugar portion were also found, with methyl hydrogens at $\delta 0.81(\mathrm{~d}, J=6 \mathrm{~Hz}, \underline{\mathbf{3}})$ and $\delta 0.92(\mathrm{~d}$, $J=6 \mathrm{~Hz}, \underline{4})$. The ${ }^{13} \mathrm{C}$ NMR spectra confirmed the structures of aglycones. The localization of the sugars in the flavonols at C-3 was indicated by $g$-HMBC experiment, which showed correlation between the anomeric hydrogen at $\delta 5.47$ and olefinic carbon at $\delta 132$ for $\underline{\mathbf{3}}$, and $\delta 5.24$ and $\delta 135.9$ for $\underline{\mathbf{4}}$. The ${ }^{1} \mathrm{H}$ NMR of $\underline{\mathbf{5}}$ and $\underline{\mathbf{6}}$ showed signals that suggested the structure of flavonol miricetin to aromatic systems. Hydrogens at $\delta 2.40-3.10, \delta 4.00(\underline{\mathbf{5}})$ and $\delta$ $5.54(\underline{6})$ indicated an oxygenated aliphatic portion in the compounds. The ${ }^{13} \mathrm{C}$ NMR spectra confirmed compounds as flavan-3-ols, due to signals at $\delta 28$ and $25.9(\mathrm{C}-4), \delta 64.9$ and $68.7(\mathrm{C}-3)$ and $\delta 78.1$ and $77.4(\mathrm{C}-2)$ to $\underline{\mathbf{5}}$ and $\underline{\mathbf{6}}$, respectively, besides signals at $\delta 165.3$, $121.2,109.3,138.1$ and 145.2 belonging gallate for $\underline{\mathbf{6}}$. The localization of the gallate in the flavan-3-ol was indicated by chemical shifts of C-2, C-3 and C-4. According to Agrawal ${ }^{10}$, esterification by gallic acid causes an expected $2-3$ ppm downfield shift of the C-3 signal, and upfield shifts of $0.5-1.5 \mathrm{ppm}$ of C-2 and $2-3$ ppm of C-4 resonances.

All isolated compounds $\left(5 \mathrm{mg} \mathrm{mL}^{-1}\right)$ were submitted to antioxidant test with a solution of $\beta$-carotene in $\mathrm{CH}_{2} \mathrm{Cl}_{2}$ on TLC plates. After four hours, compounds $\underline{\mathbf{3}}, \underline{\mathbf{4}}$ and $\underline{\mathbf{6}}$ exhibited orange spots strongly suggesting that they are responsible for antioxidant activity previously detected in the ethyl acetate extract.

\section{EXPERIMENTAL PART}

\section{General procedures}

NMR spectra were recorded on a Varian As 500 (500 MHz for ${ }^{1} \mathrm{H}, 125 \mathrm{MHz}$ for ${ }^{13} \mathrm{C}$ ) spectrometer. Chemical shifts ( $\delta$ in ppm) are given from internal standard $\mathrm{CHCl}_{3}$ (7.26) for ${ }^{1} \mathrm{H} \mathrm{NMR}$, ${ }^{13} \mathrm{CDCl}_{3}$ (77.0) for ${ }^{13} \mathrm{C} \mathrm{NMR}$. Column chromatography was performed on Silica flash (35-70 mesh) and Sephadex LH-20. TLC analysis was carried out on silica gel $60 \mathrm{~F}_{254}$ plates. Spots were visualized by absorption of UV radiation and anisaldehyde 
<smiles>C[C@H]1CC[C@]2(C)CC[C@]3(C)C(=CCC4[C@@]5(C)CC[C@H](O)C(C)(C)C5CC[C@]43C)C2[C@@H]1C</smiles><smiles>O=C(O)c1cc(O)c(O)c(O)c1</smiles><smiles>[R]c1cc(-c2oc3cc(O)cc(O)c3c(=O)c2OCCO)cc(O)c1O</smiles>

Figure 1. Substances isolated of leaves from Chrysophyllum marginatum

$2 \%$ in $\mathrm{H}_{2} \mathrm{SO}_{4}$ after heating. Antioxidant zones were detected using a solution of $\beta$-carotene in $\mathrm{CH}_{2} \mathrm{Cl}_{2}$ on TLC plates. The solvents were evaporated in Büchi Rotary Evaporator.

\section{Plant material}

Chrysophyllum marginatum (Hook. \& Arn.) Radlk (Sapotaceae) was collected in Fortaleza-Ripasa Farm, in Ibaté - SP, Brazil in March 2003. A voucher specimen (Cavalheiro 1001) is deposited at the Instituto de Botânica of São Paulo, Brazil.

\section{Antioxidant assay}

\section{Bleaching of $\beta$-carotene on TLC Plates}

Samples were eluted on TLC plates which were then dried and sprayed with $0.02 \%$ solution of $\beta$-carotene (Aldrich) in $\mathrm{CH}_{2} \mathrm{Cl}_{2}$. Plates were placed under natural light until discoloration of background. The remaining yellow spots indicated the presence of antioxidants substances ${ }^{14}$.

\section{Extraction and isolation}

Dried and powdered leaves $(212.0 \mathrm{~g})$ of $C$. marginatum were successively extracted with ethanol at room temperature. The EtOH extract was evaporated in vacuo to give a crude extract $(52.5 \mathrm{~g})$. The extract $(25.0 \mathrm{~g})$ was solubilized in $\mathrm{MeOH}-\mathrm{H}_{2} \mathrm{O}(8: 2)$ and partitioned into hexane $(5.3 \mathrm{~g})$, ethyl acetate $(3.1 \mathrm{~g})$ and $n$-butanol $(11.7 \mathrm{~g})$. The resulting extracts were tested as for antifungal, antitumoral and antioxidant ( $\beta$-carotene) activities, giving positive for the antioxidant test in the extract AcOEt. The crude AcOEt extract $(3.1 \mathrm{~g})$ was fractioned on Sephadex LH-20 eluted with $\mathrm{MeOH}$, and after analysis by TLC (AcOEt-MeOH 85:15), resulting in 30 subfractions. Subfraction 8 gave gallic acid (․․ $70.0 \mathrm{mg})$, subfraction 12 gave myricitrin $(\underline{\mathbf{4}}, 208.0 \mathrm{mg})$ and subfraction 21 gave (-)-epigallocatechin-3-O-gallate $(\underline{\mathbf{6}}, 47.0 \mathrm{mg})$. Subfraction 4
(190.0 mg) was submitted to column chromatography on Silica flash eluted with Hex- AcOEt with increasing polarity to give 12 fractions which one was identified as $\alpha$-amirin $(\underline{\mathbf{1}}, 4.0 \mathrm{mg})$. Subfraction $11(37.0 \mathrm{mg})$ was applied to preparative TLC $(5 \mathrm{x}$ AcOEt $+1 \% \mathrm{HAc})$ yielding quercitrin $(\underline{\mathbf{3}} ; 5.3 \mathrm{mg})$ and $\underline{\mathbf{4}}(9.8 \mathrm{mg})$. Subfraction 14, after preparative TLC $(3 \times$ AcOEt $+1 \%$ HAc) afforded (-)-epigallocatechin $(\underline{\mathbf{5}}, 25.3 \mathrm{mg})$. All the isolated substances were tested with solution of $\beta$-carotene in $\mathrm{CH}_{2} \mathrm{Cl}_{2}$ on TLC plates (silica gel, AcOEt-MeOH 8:2).

$\boldsymbol{\alpha}$-amirin (1) was isolated in $0.129 \%$ yield from the AcOEt extract of the leaves of $C$. marginatum by a combination of Sephadex LH20 and Silica flash chromatography. The ${ }^{1} \mathrm{H}$ and ${ }^{13} \mathrm{C}$ NMR data, in $\left(\mathrm{CD}_{3}\right)_{2} \mathrm{CO}$, were in accordance with those reported in ref. 11 .

gallic acid (2) was isolated in $2.258 \%$ yield from the AcOEt extract of the leaves of $C$. marginatum by Sephadex LH-20. The ${ }^{1} \mathrm{H}$ and ${ }^{13} \mathrm{C}$ NMR data, in DMSO- $\mathrm{d}_{6}$, were in accordance with those reported in ref. 10 and 12.

quercitrin ( $\underline{\mathbf{3}}$ ) was isolated in $0.171 \%$ yield from the AcOEt extract of the leaves of $C$. marginatum by a combination of Sephadex LH20 and preparative TLC. The ${ }^{1} \mathrm{H}$ and ${ }^{13} \mathrm{C}$ NMR, in DMSO- $\mathrm{d}_{6}$, were in accordance with those reported in ref. 10.

myricitrin (4) was isolated in $6.710 \%$ yield from the AcOEt extract of the leaves of $C$. marginatum by Sephadex LH-20. The ${ }^{1} \mathrm{H}$ and ${ }^{13} \mathrm{C}$ NMR data, in $\left(\mathrm{CD}_{3}\right)_{2} \mathrm{CO}$, were in accordance with those reported in ref. 10 .

(-)-epigallocatechin $(\underline{\mathbf{5}})$ was isolated in $0.816 \%$ yield from the AcOEt extract of the leaves of $C$. marginatum by a combination of Sephadex LH-20 and preparative TLC. The ${ }^{1} \mathrm{H}$ and ${ }^{13} \mathrm{C}$ NMR, in DMSO- $\mathrm{d}_{6}$, were in accordance with those reported in ref. 10,12 and 13 .

(-)-epigallocatechin-3-O-gallate (ㅁ) was isolated in $1.516 \%$ yield from the AcOEt extract of the leaves of $C$. marginatum by Sephadex LH-20. The ${ }^{1} \mathrm{H}$ and ${ }^{13} \mathrm{C}$ NMR data, in $\left(\mathrm{CD}_{3}\right)_{2} \mathrm{CO}$, were in accordance with those reported in ref. 10 . 


\section{CONCLUSIONS}

The chemical study of the leaves of Chrysophyllum marginatum led to the isolation and identification of six substances. This study, therefore, improved the knowledge about secondary metabolites from one more species of the Brazilian Flora, not investigated up to now. Additionally, indicated the metabolites with antioxidant activity produced by this species.

\section{ACKNOWLEDGMENTS}

The authors are grateful to Fundação de Amparo à Pesquisa do Estado de São Paulo for financial support. The authors also acknowledge CNPq for doctor fellowship awarded to V. C. da Silva.

\section{REFERENCES}

1. Judd, W. S.; Campbell, C. S.; Kellogg, E. A.; Stevens, P. F.; Plant systematics. A Phylogenetic approach, Sinauer Associates, Inc.: USA, 1999, p. 346.

2. Pennington, T. D.; Flora Neotropica - monograph 52 Sapotaceae, The New York Botanical Garden, 1990, p.1-2.

3. Gunasekera, S. P.; Kumar, V.; Sultanbawa, M. U. S.; Balasubramaniam, S.; Phytochemistry 1977, 16, 923.
4. Charrouf, Z.; Wieruszeski, J. M.; Fkih-Tetouani, S.; Charrouf, M.; Fournet, B.; Phytochemistry 1992, 31, 2079; Alaoui, A.; Charrouf, Z.; Soufiaoui, M.; Carbone, V.; Malorni, A.; Pizza, C.; Piacente, S.; J. Agric. Food Chem. 2002, 50, 4600 .

5. Misra, G.; Banerji, R.; Nigam, S. K.; Phytochemistry 1991, 30, 2087; Nigam, S. K.; Li, X-C.; Wang, D-Z.; Misra, G.; Yang, C-R.; Phytochemistry 1992, 31, 3169; Li, X-C.; Liu, Y-Q.; Wang, D-Z.; Yang, C-R.; Nigam, S. K.; Misra, G.; Phytochemistry 1994, 37, 827.

6. Sem, S.; Sahu, N. P.; Mahato, S. B.; Tetrahedron 1993, 49, 9031; Sem, S.; Sahu, N. P.; Mahato, S. B.; Phytochemistry 1995, 38, 205; Lavaud, C.; Massiot, G.; Becchi, M.; Misra, G.; Nigam, S.K.; Phytochemistry 1996, 41,887 .

7. Jiang, Y.; Ali, A.O.; Guillaume, D.; Weniger, B.; Anton, R.; Phytochemistry 1994, 35, 1013; Nicolas, G.; Ali, A. O.; Guillaume, D.; Lobstein, A.; Weniger, B.; Anton, R.; Phytochemistry 1995, 38, 225.

8. Lorenzi, H.; Árvores brasileiras. Manual de identificação e cultivo de plantas arbóreas nativas do Brasil, 2ª ed., Ed. Plantarum: São Paulo, 1998, vol 2, p. 313

9. Luo, X-D.; Basile, M. J.; Kennelly, E. J.; J. Agric. Food Chem. 2002, 50, 1379.

10. Agrawal, P. K.; Carbon-13 of flavonoids, Elsevier Science Publishers B.V., 1989.

11. Mahato, S. B.; Kundu, A. P.; Phytochemistry 1994, 37, 1517.

12. Harborne, J. B.; The flavonoids: advances in research since 1986, Chapman \& Hall: London, 1993.

13. Foo, L.Y.; Newman. R.; Waghorn, G.; Mcnabb, W. C.; Ulyatt, M. J.; Phytochemistry 1996, 41, 617.

14. Pratt, D. E., Miller, E. E.; J. Am. Oil Chem. Soc. 1984, 61, 1064. 